DOI: 10.31392/NPU-nc.series14.2019.27.22

УДК 781.41:159.955 “19”

Чжоу Сіньюй

\title{
Поліфонічна форма музики ХХ століття як тип письма та спосіб мислення
}

\begin{abstract}
У статті актуалізовано значення поліфонічного принципу створення та осягнення художніх образів для формування поліфонічного мислення майбутнього вчителя музичного мистецтва. Уточнено та висвітлено основні види поліфонічного письма музичних творів ХX століття як форми поліфонічного мислення. Багатоголосся вважається найвищим рівнем музичної організації, де основною формою, що демонструє взаємодію поліфонії та гармонії на основі імітації, є фуга. Музичне мислення в цій формі виявляється у діалектичному сполученні його протилежностей - горизонтальному та вертикальному за принципом безперервності, єдності та контрасту. Розглянуто новий вид письма музичного тексту на основі ритму та тембру: лінія, крапка, комплекс. На основі сучасних засобів музичного письма (пуантилізм, сонористика, додекафонія, гемітоніка, колаж) виділено способи поліфонічного мислення композиторів XX століття : ритмічну поліфонію; поліфонію тембрів; мікрополіфонію; надбагатоголосся. Передбачається, що вивчення та виконання поліфонічних творів композиторів різних епох допоможе у формуванні поліфонічного мислення студентів - майбутніх вчителів музичного мистецтва.
\end{abstract}

Ключові слова: вчитель музичного мистецтва; мікрополіфонія; поліфонія тембрів; ритмічна поліфонія.

Актуальність. Сучасне художне сприйняття світу вимагає пізнання життя в його багатогранності та поліфонічності. Поліфонічний принцип створення та осягнення художніх образів проявляється сьогодні у всіх видах мистецтва - музиці, літературі, образотворчому мистецтві, хореографії, екранних видах мистецтва. Розгляд творів мистецтва і культурних явищ в їх "поліфонічності" забезпечується властивістю поліфонії поєднувати окремі самостійні плани в одному мистецькому образі. Це створює єдність множинності у творі та уможливлює цілісність його буття як феномена художнього світосприйняття.

Відомо, що під музичною поліфонією розуміють вид багатоголосся, де окремі голоси мають рівноправне значення при самостійному інтонаційно-ритмічному розвитку, розбіжностях каденцій, цезур, кульмінацій, акцентів тощо. Одночасне буття мелодичних, тембральних, ритмічних, гармонічних пластів музичного твору вимагає розвиненості поліфонічного слуху та сформованості поліфонічного мислення як слухача, так і виконавця, зокрема, майбутнього вчителя музичного мистецтва.

Вивченням теорії поліфонії в системі музичного мислення займались Ю. Алієв, Г. Гельмгольц, А. Дмитрієв, 3. Рінкявічюс, М. Ройтерштейн, Г. Побережна, О. Полатайко, М. Сибірякова-Хіхловська, Сяо Лі, І. Чижик, Т. Щериця, К. Южак та інші. Проблему розвитку поліфонічного слуху та його специфіки розглядали Г. Дубінін, А. Каузова, Т. Курасова, Г. Меліксетян, С. Пермінова, В. Спиридонова, Л. Степанова та інші. Розвиток сучасної поліфонії став змістом наукового інтересу М. Лобанової, В. Задерацького, Л. Кияновської, О. Козаренка, Н. Гуляницької, Б. Сюти та інших.

Науково-педагогічний досвід багатьох дослідників показав, що самостійний аналіз та вивчення поліфонічних творів викликає у студентів певні труднощі. Це зумовлено відсутністю теоретичної підготовки студентів, а також складністю сприйняття та виконання поліфонічної фактури музичних творів різних часів. Набуття таких знань 3 історії та теорії поліфонії, а також навичок сприйняття та виконання поліфонії $\epsilon$ основною умовою формування поліфонічного мислення майбутніх вчителів музичного мистецтва. Разом з тим, залишається недостатньо вивченою роль поліфонічної фактури музичних творів XX століття в формуванні поліфонічного мислення студентів.

Мета статті - окреслити основні види поліфонічного письма XX століття задля залучення поліфонічних творів у роботу зі студентами (майбутніми вчителями музичного мистецтва). 
Сучасні науковці вважають, що наше життя поліфонічне, а багатоголосний хор підходів, ідей, бачення і сенсів є властивістю сучасного світу. Проте, не всяке багатоголосся можна назвати поліфонією, а лише таке, де кожен голос має свою цінність, виразність, а в поєднанні 3 іншими утворює гармонійну цілісність. У цьому зв'язку, людину очікують важливі інтегративні процеси, що відбуваються в контексті класично організованої картини світу, зокрема, в єдності різноманіття. Ця точка зору є певним наслідуванням ідей

знавця поліфонії XX століття К. Южак щодо гнучкості меж поміж поліфонічним та гомофонним складами як системними елементами, що мають змінний характер власної структури при загальній цілісності. Спираючись на розуміння структури як принцип, спосіб, закон зв'язку елементів цілого, а також на систему відносин між такими елементами, К. Южак акцентує увагу на мінливості таких зв'язків на різних рівнях музичного мистецтва [6], $[14$, c.7]. «Поліфонія і гомофонія як загальні елементи містять голоси, а точніше, лінії (лінія може бути одноголосною або пластом), проте структурні зв'язки голосів у цих складах $\epsilon$ діаметрально протилежними, що впливає на суттєві властивості самих голосів. У гомофонії голоси $\epsilon$ функціонально неоднорідними, нерівноправними, у виразному сенсі нерівнозначними. Натомість в поліфонії голоси $\epsilon$ функціонально однорідними, рівноправними, у виразному - рівнозначними. Таким чином, супідрядність голосів у гомофонії грунтується на функціональній диференціації, на виділенні головного голосу і супроводу, а в поліфонії - на функціональній спільності та суголосності» [14, с.7].

Поліфонічній музиці властива плинність. Відомо, що поліфонічний склад не містить ритмічного повторення, симетрії, спільних цезур, а неодночасний початок та закінчення звучання голосів створюють неперервність музичної думки. Спільна думка, що об'єднує музичний матеріал, уможливлює створення поліфонічного ансамблю за рахунок взаємодії голосів, гармонічної, тональної та стилістичної єдності. Музикознавці С.Савшинський та Г. Курковський вважали поліфонію особливим видом музичної мови, музичного висловлювання та видом музичного мислення.

Поліфонічне багатоголосся вважається найвищим рівнем музичної організації. Основною формою, що демонструє взаємодію поліфонії та гармонії на основі імітації, є фуга. Музичне мислення в цій формі виявляється у діалектичному сполученні його протилежностей горизонтальному та вертикальному. Рух голосів у лінійній та вертикальній взаємодії стає істотною трудністю для сприйняття твору та роботи над його виконанням.

Поліфонічний виклад відбувається за трьома основними принципами - безперервності, єдності та контрасту. I якщо принцип безперервності проявляється у горизонталі, то принципи єдності і контрасту існують у двох площинах, що перетинаються. Чинниками єдності у вертикалі стали висота звуку та міра руху. У горизонтальній площині основними $\epsilon$ чинники контрасту - інтонаційно-ритмічна координація мелодичної лінії [5]. У формі поліфонічного твору найважливішою залишається незалежність і виразна значущість кожного голосу. У розвинених формах поліфонічної музики саме єдність різного є головною, визначальною якістю, зазначає Побережна, що відповідає загальним основним принципам поліфонії [5].

Музика є складовою мистецтва, яке розвивається за законами сучасного життя. Відтак, зміни торкнулися «не лише категорій простору і часу, але й техніки письма, музичних виражальних засобів. Все це, безумовно, відбилось на особливостях стилю, жанру та форми музики ХХ століття» [11, с. 274].

Використання класичних структур та видів поліфонії (підголоскової, імітаційної, контрастної) зазнало особливої індивідуалізації в творчості композиторів XX століття. Використовуючи традиційні форми, композитори шукали та створювали індивідуальну форму. «Прагнення до поліфонізації, убачання множинності поєднувалось з орієнтацією на межову індивідуалізацію» [11], [4, с. 110-111 ].

Нове відчуття життя, Людини та Всесвіту, ставлення до мистецтва, історії та культури минулих часів як до актуального, відбились у тематиці сучасної музики про вічну боротьбу 
світла і темряви, свідомого і підсвідомого, духовного та бездуховного. Такі глибокі філософські поняття стають головними образами музичних творів у перебігу музичних виражальних засобів - зіставлення ладів, технік, тембрів, ритмів, гармонії, поліфонії, використання акордів, цитат тощо[3].

Бажання теоретизувати нову музику XX століття детермінувало інтерес до теорій О.Мессіана, П.Хіндеміта, Е.Лендвай, Б.Яворського. «Розуміючи музику як голос глибокої світової сутності, композитори у своїх творах прагнули універсальної єдності в стилі, підкреслювали в музиці минулого і сьогодення елементи „позачасові" й діалектичні, все розвивається, інтегрується та не зникає безслідно. Ось чому для них виявляється таким важливим універсальна спрямованість на полістилістику: поєднання в одному творі елементів музичної мови від бароко до сучасного шлягеру» [11, с. 274] .

Новий етап розвитку музичного мистецтва характеризувався певними змінами, одною 3 яких стала лінеарність ( на зміну гомофонно-гармонічному складу), що знайшла яскраве виявлення в додекафоній системі з опорою на техніку старої школи. Яскравим прикладом цього став тематизм, стиснений до єдиного звуку/крапки. Саме це уможливило виникнення нової оригінальної якості організації тематизму, гармонії й фактури музики XX століття пуантилізму. Спираючись на Б.Сюту, Сяо Лі зазначає, що «подрібнення мелодичних контурів, фрагментарність фактури, проникнення речитативності в інструментальний тематизм - ці фактори яскраво проявилися у розвитку системи засобів виразності музики XX століття» [11, с. 274], [10].

Отже, музичне мистецтво дістало у використання новий тип письма, що містив такі види «музичної тканини: 1) лінія: мелодична, ритмічна, тембральна; 2) крапка (або "штрих"): звукова, ритмічна, темброва; 3) комплекс: кластерна стрічка (смужка), пласт, блок (пляма)» [11, с. 274].

Ці види музичної тканини успішно використовуються композиторами в сучасних нових видах, засобах та методах музичного письма, до яких науковці відносять: пуантилізм, сонористику, додекафонію, гемітоніку, колаж [1, с. 48].

Таким чином, поліфонічність перестає бути лише якістю музичної фактури, а стає властивістю складових музичної мови - звуку, гармонії, ритму, форми. Поліфонізація музичної думки, іiі глибина й масштаб висвітлюють очевидність та актуальність розгляду питання про поліфонію XX століття у двох ракурсах - поліфонії як типу письма, поліфонії як типу мислення.

Поліфонічний аспект композиційного мислення в інструментальній музиці часто стає домінуючим, репрезентуючи музичний твір як систему співвідношень і функцій компонентів, що одночасно розвиваються.

Так, із багатьох видів фактури в сучасній музиці композитори І. Стравінський, О. Мессіан, А. Шнітке, Д. Лігеті виділяють:

- ритмічну поліфонію;

- поліфонію тембрів;

- мікрополіфонію;

- надбагатоголосся.

Розглянемо їх детальніше. Багатогранність і динамічна сила ритмічних прийомів, збагачених особливостями різних музичних культур, утворили фундамент для виникнення явища, яке може бути визначено як ритмічна поліфонія. У фактурі такого типу на перший план висувається формотворча дія ритму та роль іiї в організації голосів ритмічної фактури. На перший план висувається ритмолінія, яка являє собою лінеарно-організований компонент тканини, в якій основним єдиним засобом процесуального розвитку виявляється ритмічний малюнок. У такому випадку мелодизм ліній повинен залишатися в тіні, а на перший план висувається ритм. Загостреність ритму завжди присутня в ритмічній поліфонії, позаяк ритм у такій фактурі, як вже підкреслювалося, - це відсутність мелодичного розвитку. 
Засоби яскравого ритмічного контрасту - поліритмія, поліакцентність - посідають своє важливе місце в поліфонії такого виду [12]. Якщо ритмічна поліфонія виникає в зв’язку 3 наданням ритму тематичного значення, то тематизація тембру в умовах поліфонічного контрапунктування утворює тканину, яку можна назвати тембровою (сонорною) поліфонією.

Так звана музика тембрів специфічне явище, при якому тембр трактувався як початковий потенціал матеріалу для утворення композиції в усіх іiі елементах і параметрах. Звичайно, поліфонія тембрів пов'язана 3 виявленням неповторних тембрових барв, які проявлялися у виборі різних неординарних інструментів у незвичайному їх використанні, у створенні індивідуальних груп чистих тембрів, але своєрідність тематизованого тембру досягалася i цілим рядом спеціальних прийомів.

Контрапунктування мелодій і тембрових пластів - один із найбільш плідних форм сонорної поліфонії, так як в ній при додержанні необхідної контрастності і самостійності голосів виникає менше загроз для появи інтонаційної беззмістовності або в’ялості тематизму [1].

Мікрополіфонія - теза з найбільш оригінальних новоутворень музичної фактури XX ст., за своїм виразним потенціалом відрізняється від ритмічної і тембрової поліфонії. Це своєрідна прогресивна манера поліфонічного письма, суттю якої $є$ надзвичайно стисле висотне розташування голосів. Партитура такого твору структурована як канон, де водночас відбувається рух голосів у різних темпах і ритмічних малюнках, а кластери безперервно змінюють один одного. У подальшому цю мікрополіфонічну техніку, автором якої $\epsilon$ угорський композитор Дьєрд Лігеті, наслідували композитори ХХ століття [9].

Надбагатоголосся - тип фактури, в основі якої лежить ефект сумарного звучання багатьох індивідуальних, найчастіше поліфонічних, але не диференційованих слухом голосів, які разом складають якісно нову, нерозділену на компоненти фактурну цілісність. Володіючи яскравою характерністю звучання, така фактура привертає увагу композиторів різних творчих індивідуальностей i художньо-стильових орієнтацій (наприклад, І.Стравінський "Весна священна"). У надбагатоголоссі голос за своєю функцією виступає як елемент єдиної фактурно-інтонаційної лінії. Також, важливим елементом такої фактури, як нового музичного складу, виступає фактор особливої регістрової щільності і розташування голосів. Зміна розташування голосів 3 тісного на широке і навпаки в надбагатоголоссі неможлива. Така зміна руйнує надбагатоголосся. Щільність голосів можна визначити як принцип хроматичного фактурного хроматизму, критерієм визначення $є$ відстань між голосами звукового пласту [8, с. 49-66.].

Варто зазначити, що, крім розглянутих поліфонічних фактур $\mathrm{XX}$ століття, мистецтвознавці розглядають фактури, які мають своє відношення до вище розглянутих. Так, проста поліфонічна фактура XX століття у новаторській інтерпретації виглядає у таких формах організації: тональна, політональна, атональна. Причому, характер піi подачі пов'язаний із надзвичайною багатоманітністю регістрових, тембрових варіантів.

Контрапункт - один із фундаментальних принципів поліфонії - у новітній музиці піддався радикальним змінам, що пов'язані як з перетворенням форм мелодичної лінії, так і 3 природнім розширенням у XX столітті природи музичного матеріалу, проростання контрапункту в сучасні гармонічні системи, взаємодіючи 3 новими принципами формоутворення, ритміки, тембровими фарбами, конфігураціями музичного простору. Контрапункт та імітаційність практично нероздільні у поліфонії крапок - природним наслідком пуантилізму. 3 одного боку, при пуантилізмі активізується значення терміну контрапункт - «крапка» проти «крапки», а з іншого, ті ж крапки утворюють імітацію. При цьому основним якісним показником подібної імітації виявляється не інтервал вступу і не відстань як раніше, а тембр (разом з регістром, який безпосередньо впливає на нього) [2, c. 88.].

Поліфонія сонорних пластів складає шарову галузь із різноманітних реалізацій, комплексного шару музичної тканини. Тут можуть бути як акордові послідовності в 
тембровому трактуванні, так й інші „масштабні утворення”. При цьому в організації пластів широко використовуються й інші прийоми, в тому числі й поліфонічні, а самі пласти можуть перебувати як в контрапунктичних, так і в імітаційних відношеннях [7]. Кожен пласт сонорної поліфонії в техніці колективного ad libitum складається із декількох індивідуальних партій.

Поліфонія стилів допускає практично будь-яку їх комбінацію, навіть «дисонанс стилів» (Ю.Холопов) особливо різких, коли вони перебувають в одній «звуковій площині» [13].

Виразним новаторством в поліфонії XX століття стало викладення тематичного матеріалу: тема експонується не у вигляді одноголосної мелодичної лінії, а у формі декількох ліній, які носять гетерофонний характер. Щодо тематичного матеріалу в інших голосах, то він викладається 3 невеликими ритмічними видозмінами. Така мікроканонічна техніка (вперше застосована для експонування тем фуги) часто використовується різними композиторами. Фуга в XX столітті продовжує зберігати своє значення вищої поліфонічної форми.

Отже, вивчення та виконання поліфонічних творів композиторів різних епох допоможе у формуванні поліфонічного мислення студентів - майбутніх вчителів музичного мистецтва. У подальшому науковим інтересом стануть методичні аспекти формування поліфонічного мислення студентів на основі вивчення музики XX століття.

\section{Література}

1. Дувірак Д. Сонорні засоби музичної виразності в творчості українських радянських композиторів. Украӥнське музикознавство: (республіканський міжвідомчий науково-методичний збірник). К. : Музична Україна, 1988. [Вип. 23]. С. 48-54.

2. Завгородняя Г. Полифонические основы современного композиторского творчества. Аналитические очерки. Одесса : Астропринт, 2012. 308 с.

3. Заверуха С. Поліфонія у структурі системи ступеневої підготовки вчителя музики, етики i естетики [Текст] : [посібник]. Хмельниц. гуманітар.-пед. акад. Хмельницький : Заколодний М. І., 2014. $243 \mathrm{c}$.

4. Лобанова М. Музыкальный стиль и жанр: история и современность. Серія: Письмена времени. М : Центр гуманитарных инициатив, 2015. 208 с.

5. Побережна Г., Щериця, Т. Загальна теорія музики: підручник. К. : Вища шк., 2004. 303c.

6. Полатайко О., Сяо Лі. Діалектичний аспект формування поліфонічного мислення студентівмузикантів педагогічного профілю. Науковий часопис Національного педагогічного університету імені М.П.Драгоманова. Серія 14. Теорія і методика мистецької освіти: Зб. Наук. Праџь. К. : 2016. Вип. 20 (25). С. 28-34.

7. Скребков С. Теория имитационной полифонии. Киев : Муз. Украіна, 1983. 144 с. .

8. Сниткова И. Специфика "полифонической" структуры сверхмногоголосия. Современное искусство музыкальной композиции: Сб. тр. ГМПИ им. Гнесиных. Вып.79. М., 1985. С.51-67.

9. Способин И. Музыкальная форма : учебник общ. курса анализа. М. : Музыка, 2007. 398 с.

10. Сюта Б. Проблеми організації художньої цілісності в українській музиці другої половини ХХ століття. К. : НАН України ІМФЕ ім. М. Т. Рильського, 2004. 118 с.

11. Сяо Лі. Феномен поліфонічного мислення в сучасній музиці. Педагогічна майстерність як система професійних і мистецьких компетентностей: зб.матеріалів ХІІІ Міжнар. Педагогічномистеиьких читань пам'яті проф. О.П.Рудницькой/ [голов. ред. Г. І. Сотська]. Вип. 7 (11). - К.: Талком, 2016. С.272-276.

12. Холопова В. Вопросы ритма в творчестве композиторов XX века. Музыка, 2003. 304 с.

13. Холопова В.Фактура. М. : Музыка, 1979. 87 с.

14. Южак К. О природе и специфике полифонического мышления. Полифония. Сборник статей. Сост. и ред. К.Южак. М. : Музыка, 1975. С.6-62.

Про автора:

Чжоу Сіньюй, аспірант, Національний педагогічний університет імені М.П. Драгоманова (01054 Київ, Україна); ORCID: 0000-0001-5501-6980 


\section{Polyphonic music form of XX century as a type of composing and a way of thinking}

Zhou Xinyu

Relevance of the study. The polyphonic principle of creating and comprehending art images is manifested in all kinds of art. Musical polyphony is a kind of polyphonic voices, where individual voices are equally important in independent intonational rhythmic development. This requires the polyphonic thinking of a future music teacher. Today it is known that independent analysis and study of polyphonic works cause some difficulties for students.

Literature review. The theory of polyphony in the system of musical thinking was studed by Y. Aliyev, G. Helmholtz, A. Dmitriev, Z. Rinkyavichyus, M. Reiterstein, G. Poberezhnaya, O. Polataiko, M. Sibiriakova-Khikhlovskaya, Xiao Li, I. Chizhik, T. Shcherytsya, K. Yuzhak and others. The problem of the development of polyphonic hearing was studied by G. Dubinin, A. Kauzova, T. Kurasov, G. Meliksetian, S. Perminova, V. Spiridonova, L. Stepanova and others. Modern polyphony is the content of scientific interest of M. Lobanova, S. Pavlyshyn, L. Kiyanovskaya, O. Kozarenko, N. Gulyanytska, B. Suta and others.

Purpose - to clarify and highlight the main types of polyphonic writing of XX century music as a form of polyphonic thinking.

Results. Music develops according to the laws of modern life. Therefore, the changes affected writing techniques, musical expressive means. The use of classical structures and types of polyphony (sub-voice, imitation, contrast) was especially individualized in the work of the twentieth century composers. Deep philosophical concepts become the main images of musical works containing juxtapositions of frets, techniques, timbres, rhythms, harmony, polyphony, the use of chords and more. The new stage in the development of musical art was characterized by linearity, which found a striking manifestation in the dodecaphonic system with a reliance on old-school technique. Musical art used a new type of writing that contained the following types of musical text: 1) line: melodic, rhythmic, timbral; 2) dot (or stroke): sound, rhythmic, timbre; 3) complex: cluster strip, layer, block (spot). Counterpoint - the fundamental principle of polyphony has undergone radical changes, interacting with new principles of formation, rhythmic, timbre colours, configurations of musical space. Counterpoint and imitation are virtually inseparable in the polyphony of dots - a natural consequence of pointillism. The polyphony of sonar layers is a layer branch of various realizations, a complex layer of musical fabric. Each layer of sonar polyphony in the collective ad libitum technique consists of several individual batches. Polyphony of styles allows practically any combination of them, even dissonance of styles especially sharp when they are in one sound plane. A clear innovation in the polyphony of the twentieth century was the presentation of thematic material: the theme is exhibited not in the form of a unanimous melodic line, but in the form of several lines that are heterophone. The fugue in the twentieth century continues to retain its importance of higher polyphonic form.

Conclusions. We have identified the main types of polyphonic writing and types of texture of the twentieth century. Studying and performing polyphonic works by composers of different eras will help to form the students' polyphonic thinking.

Keywords: micropolyphony; music teacher; polyphony of timbres; rhythmic polyphony.

\section{References}

1. Duvirak D. Sonorni zasoby muzychnoi vyraznosti v tvorchosti ukrainskykh radianskykh kompozytoriv [Sonorous means of musical expression in the works of Ukrainian Soviet composers]. Ukrainske muzykoznavstvo: (respublikanskyi mizhvidomchyi naukovo-metodychnyi zbirnyk). K. : Muzychna Ukraina, 1988. Vyp. 23. S. 48-54. [in Ukrainian]

2. Zavgorodnyaya G. Polifonicheskie osnovy sovremennogo kompozitorskogo tvorchestva. Analiticheskie ocherki. [Polyphonic basics of contemporary composer creativity. Analytical essays]. Odessa : Astroprint, 2012. 308 s. [in Russian]

3. Zaverukha S. Polifoniia u strukturi systemy stupenevoi pidhotovky vchytelia muzyky, etyky i estetyky: posibnyk. [Polyphony in the structure of the system of step training of the music, ethics and esthetics teacher]. Khmelnyts. humanitar.-ped. akad. Khmelnytskyi : Zakolodnyi M. I., 2014. 243 s. [in Ukrainian]

4. Lobanova M. Muzykalnyy stil i zhanr: istoriya i sovremennost [Musical style and genre: History and modernity]. Seriya: Pismena vremeni. M: Tsentr gumanitarnykh initsiativ, 2015. 208 s. [in Russian]

5. Poberezhna H., Shcherytsia, T. Zahalna teoriia muzyky [General musical theory]: pidruchnyk. K. : Vyshcha shk., 2004. 303 s. [in Ukrainian]

6. Polataiko O., Xiao Li. Dialektychnyi aspekt formuvannia polifonichnoho myslennia studentivmuzykantiv pedahohichnoho profiliu [Dialectical aspects of the formation of polyphonic thinking of students- 
musicians pedagogical]. Naukovyi chasopys Natsionalnoho pedahohichnoho universytetu imeni M.P.Dragomanova. Seriia 14. Teoriia i metodyka mystetskoi osvity: Zb. Nauk. Prats. K. : 2016. Vyp. 20 (25). S. 28-34. [in Ukrainian]

7. Skrebkov S. Teoriya imitatsionnoy polifonii [Theory of Imitation Polyphony]. Kiev : Muz. Ukraina, 1983. 144 s. [in Russian]

8. Snitkova I. Spetsifika "polifonicheskoy" struktury sverkhmnogogolosiya [The specificity of the "polyphonic" structure over polyphony]. Sovremennoe iskusstvo muzykalnoy kompozitsii: Sb. tr. GMPI im. Gnesinykh. Vyp.79. M., 1985. S.51-67. [in Russian]

9. Sposobin, I. V. Muzykalnaya forma [Musical form] : uchebnik obshch. kursa analiza. M. : Muzyka, 2007. 398 s. [in Russian].

10. Siuta B. Problemy orhanizatsii khudozhnoi tsilisnosti v ukrainskii muzytsi druhoi polovyny XX stolittia [Problems of organization of artistic integrity in Ukrainian music of the second half of XX century]. K. : NAN Ukrainy IMFE im. M. T. Rylskoho, 2004. 118 s. [in Ukrainian]

11. Xiao Li. Fenomen polifonichnoho myslennia v suchasnii muzytsi [The phenomenon of polyphonic thinking in contemporary music]. Pedahohichna maisternist yak systema profesiinykh $i$ mystetskykh kompetentnostei: zb.materialiv XIII Mizhnar. Pedahohichno-mystetskykh chytan pamiati prof. O.P.Rudnytskoi / [holov.red.H.I.Sotska]. Vyp. 7 (11). K. : Talkom, 2016. S.272-276. [in Ukrainian]

12. Kholopova V. Voprosy ritma $\mathrm{v}$ tvorchestve kompozitorov 20 veka [The problem of rhythm in the work of the twentieth century composers]. Muzyka, 2003. 304 s. [in Russian]

13. Kholopova V.Faktura. M.: Muzyka, 1979. 87 s. [in Russian]

14. Yuzhak K. O prirode i spetsifike polifonicheskogo myshleniya [About the nature and specifics of polyphonic thinking]. Polifoniya. Sbornik statey. Sost. i red. K.Yuzhak. M. : Muzyka, 1975. S.6-62. [in Russian]

About the author:

Zhou Xinyu, postgraduate student at the Faculty of Arts, National Pedagogical Dragomanov University (01054, Kyiv, Ukraine); ORCID: 0000-0001-5501-6980 